\title{
Financial Development And Growth In Middle Eastern Countries
}

Mounther Barakat, Securities and Commodities Authority, United Arab Emirates Edward Waller, University of Houston-Clear Lake, USA

\begin{abstract}
This paper studies the relationship between financial intermediation and economic growth in a sample of Middle Eastern countries. The results are consistent with the hypothesis that a wellfunctioning banking system promotes economic growth. Moreover, the results suggest that market-specific factors may hinder financial markets' ability to play hypothesized roles, while enhancing the role of intermediaries. The paper's general conclusion is that financial development does affect economic growth. However, market specific factors affect the magnitude and significance of this effect. The implication is that studies should control for market-specific factors to assess the relationship between financial development and growth.
\end{abstract}

Keywords: economic growth, financial development, country factors

\section{INTRODUCTION}

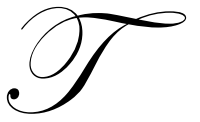

he relationship between financial development and economic growth has been extensively studied. For example, Goldsmith (1969), McKinnon (1973), and Shaw (1973) produced considerable evidence that the level of financial development is correlated with economic growth more than forty years ago. In traditional growth theory, financial intermediation can be related to the level of the capital stock per worker or to the level of productivity, but not to growth rates (Pagano, 1993). While endogenous growth models show there can be self-sustaining growth without exogenous technical progress, these models have also shown that growth can be related to preferences, technology, income distribution, and institutional arrangements. In essence, these models suggest a relationship between financial development and growth and can be used as the basis for empirical tests of the effects of development on growth.

In this paper, we examine the financial development - growth relationship in Middle Eastern countries. The empirical results are not consistent with the view that financial market development facilitates economic growth in Middle Eastern countries. However, the results are consistent with the view that financial intermediation promotes economic development. Moreover, the results suggest that country-specific factors can enhance or mitigate the role of intermediaries in growth.

The remainder of this paper is organized as follows. Section 2 surveys the theoretical literature about the causal relationship between financial development and growth, while section 3 summarizes empirical literature. Section 4 describes methodology. Section 5 presents results. We conclude with a summary and suggest implications for future work.

\section{RELATIONSHIP BETWEEN DEVELOPMENT AND GROWTH}

Arrow (1964) and Debreu (1959) suggest in a state-contingent claim framework with no information or transaction costs there is no need for a financial system that dedicates resources to researching projects, scrutinizing managers, or facilitating risk management. Alternatively, Merton and Bodie (1995) suggest the financial system exists to mitigate transaction and information costs by facilitating the allocation of resources under uncertainty. Levine (1997) argues this function consists of five basic functions: (1) facilitating the trading, hedging, diversifying and pooling of risk; (2) allocating resources; (3) monitoring managers and resolving corporate control issues; (4) 
mobilizing savings; and (5) facilitating the exchange of goods and services.

These views suggest financial intermediaries enhance financial development by allocating funds to those projects where the marginal product of capital is highest, promoting economic growth. This promotion consists of two components: analyzing information to evaluate alternative investment projects and inducing individuals to invest in riskier but more productive projects by providing risk sharing (Jovanovic, 1990). Financial intermediaries with large well-diversified portfolios may be more risk tolerant than individual investors because intermediaries can more readily absorb exogenous shocks, facilitating investment in riskier projects with higher values. Thus, savings that are invested through intermediation may be allocated more efficiently, leading to higher productivity of capital and faster growth.

Moreover, intermediaries pool the liquidity risk of depositors and invest funds in more illiquid and productive projects without exceeding the expected withdrawals by depositors who may be adversely affected by liquidity shocks. Households, on the other hand, may invest in productive assets that can be promptly liquidated, thus forgoing investments that are more productive, but also more illiquid. The effects of this inefficiency may be mitigated by financial intermediation. In particular, Diamond and Dybvig (1983) suggest banks increase the productivity of investment both by directing funds to illiquid, high-yield investments and by reducing investment waste from premature liquidation, which would occur when individuals face liquidity shock. This productivity gain leads to faster growth.

Securities markets also provide liquidity without discontinuing productive projects by liquidating financial stakes in these projects in the secondary market and facilitating diversification without requiring larger outlays (Levine 1991). This function increases investor willingness to invest in less liquid, more productive projects and avoids unnecessary terminations. As a result, market and intermediary development may increase productivity of investment and economic growth.

In addition, as markets develop, households may develop better insurance against credit risk. Markets may also become more efficient, and the creditworthiness of deficit units may be assessed more rigorously, and information may be more readily available. Thus, search costs and interest spreads may be lower, encouraging transfers from surplus to deficit units. In essence, intermediary development may reduce the demand for precautionary cash balances and directs those balances towards productive assets that facilitate growth.

However, Devereux and Smith (1991) suggest that, in an endogenous growth model, the fall in the precautionary saving rate lowers the growth rate, providing an example in which financial development retards growth. Bencivenga and Smith (1991) argue that the existence of financial markets and institutions may reduce savings rates, while Saint-Paul (1992) suggests risk sharing increases savings. Regardless, gross savings may be larger than gross investment because financial intermediaries consume savings in the form of the spread between lending and borrowing rates, as well as in the form of commissions and fees. This consumption can be viewed as equilibrium compensation for services rendered, as well as compensation for taxation, reserve requirements, and transaction costs. If financial development reduces this leakage, development can increase growth rates because the amount invested becomes higher (Pagano 1993). Moreover, financial monopolies and the lack of competition widen the margins charged by financial intermediaries. Margins affect capital accumulation via their incentive effect on saving and keep the interest rate paid to savers below the prevailing interest rate in perfect capital markets. The converse is true for borrowers (McKinnon, 1973).

\section{EMPIRICAL RELATIONSHIP BETWEEN DEVELOPMENT AND GROWTH}

The effects of financial development on growth have also been examined extensively in prior empirical work. These studies attempt to answer two questions: (1) is there a causal relationship between financial development and growth? and (2) if financial development enhances economic growth, does it do so by enhancing the efficiency of investment or by increasing the portion of saving that is actually invested?

Specifically, Greenwood and Jovanovic (1990) and Saint-Paul (1992) use endogenous models to determine the magnitude and direction of the relationship between economic growth and financial development to test whether 
economic growth is a determinant of the degree of financial intermediary development. Roubini and Sala-i-Martin (1992) argue governments may pursue financial repression to raise tax revenue and seigniorage, to execute a more efficient monetary policy, to insure safety and transparency to investors and to achieve economic growth, while recognizing adverse effects on growth. Tsiddon (1992) demonstrates capital market imperfections result from informational asymmetries between lenders and borrowers and suggests this phenomenon produces adverse selection and moral hazard problems. Sussman (1991) argues that the cost of financial intermediation may decrease due to economies of scale and the aggressive competition between financial intermediaries.

King and Levine (1992) also suggest growth correlates with many indicators of financial development in cross-country data. However, their findings are inconclusive with respect to the relative importance of efficiency and the rate of investment. Roubini and Sala-i-Martin (1991) examine policy variables that affect financial markets but are unaffected by growth. They find growth is negatively correlated with the bank reserve ratio $\sim$ an institutional constraint that is unlikely to be affected by growth. Atje and Javanovic (1992) find evidence that the relative size of the stock market affects growth in per capita gross domestic product, while King and Levine (1993a) use a 29 year data set from 80 countries and find that various measures of the level of financial development are strongly associated with real per capita GDP growth, the rate of physical capital accumulation and improvements in the efficiency with which economies employ capital. King and Levine (1993b) suggest that better financial systems stimulate faster productivity growth and growth in per capita output by funneling society's resources to promising productivity-enhancing endeavors.

Similarly, Demirguc-Kunt and Maximuvic (1996) show that firms in countries with better functioning banks and equity markets grow faster than would otherwise be predicted by individual firm characteristics. Levine and Zervos (1998) demonstrate stock market liquidity and banking development predict growth, capital accumulation and productivity improvement even when controlling for economic and political factors. In contrast, Harris (1997) finds no hard evidence that the level of stock market activity helps to explain growth in per capita output.

Garretsen et al (2003) find legal variables and social norms are important in explaining stock market capitalization and economic growth. Using data from Greece, Hondryiannis et al (2004) use VAR models and establish a bi-directional causality between finance and growth. They also use error-correction models to find that both bank and stock market financing can promote economic growth in the long run. However, the effect is small and the contribution of stock market finance to economic growth is substantially smaller than bank finance. This result suggests that the financial development - economic growth relationship is affected by countries' institutional and cultural settings. Bolbol et al (2004), using data from Egypt, control for country specific factors and finds market development benefits total factor productivity.

Levine (1997) suggests financial development causes growth, while Rajan and Zingales (1998) provide evidence that industrial sectors that are relatively more in need of external finance develop disproportionately faster in countries with more developed financial markets. In effect, industries that generate more cash flow grow relatively faster in countries with more underdeveloped financial markets, suggesting that market imperfections affect investment and growth. In essence, Rajan and Zingales find evidence that supports the hypothesis of a causal link between financial development and growth where growth is caused by financial development. Filer et al (1999) uses Granger-causality tests and provides evidence of a positive and significant causal relationship from stock market development to economic growth, particularly in less developed countries.

We contribute to this literature in this paper by examining the financial development - growth relationship in Middle Eastern countries. Specifically, we add to the literature by providing results for countries with distinctive institutional and cultural infrastructures. The results suggest that country-specific and institutional factors hinder financial markets ability to play their hypothesized role while enhancing the banking industry's role in economic development. 


\section{METHODOLOGY}

The literature suggests the development of financial markets and institutions mitigate adverse selection and moral hazard problems, implying a lower cost of external financing. One implication of this view is that market and intermediary development facilitates economic growth. For example, Rajan and Zingales (1998) hypothesize industries that are more dependent on external financing will have relatively higher growth rates in countries that have more developed financial markets. We generalize this hypothesis by suggesting countries that depend on intermediaries to finance growth should have higher growth rates if intermediaries are more developed.

We use proxies for growth and development similar to those used in previous studies. Specifically, Rajan and Zingales (1998) suggest that the level of credit and the size of the stock market typically measure financial development. These two variables predict economic development because financial markets anticipate future growth. The stock market capitalizes the present value of growth opportunities, while financial institutions lend more if sectors are likely to grow. Levine and Zervos (1998) use measures of market liquidity and stock market size to proxy for the level of financial development. Atje and Jovanovic (1992) use trading volume on the stock market scaled by GDP and the total stock market trading volume divided by market capitalization. Jappelli and Pagano (1992) use saving and growth rates for economic growth and consumer credit to GDP and the maximum loan-tovalue ratio in the mortgage market as proxies for financial development. Levine (1997) notes that, in addition to size measures, other studies use three alternative measures of the level of financial development to more precisely gage the functioning of financial systems. These variables are: the size of financial intermediaries relative to Gross Domestic Product (GDP), bank credit relative to bank credit plus central bank domestic assets, the ratio of credit allocated to private enterprises to total domestic credit, and credit to private enterprise relative to GDP. Levine also notes that economic growth can be proxied by per capita GDP, GDP growth, capital accumulation, and productivity growth.

As in prior work, we use domestic credit to GDP to capture the role of banking in economic growth. Since it is less costly to liquidate stocks than to severe banking relationships or liquidate existing projects, market liquidity may have a positive effect on economic development. Moreover, increased volume is also consistent with increased portfolio activity, including monitoring activity, facilitating faster growth. We use trading volume as a percentage of GDP to measure market liquidity and suggest that economic growth should be positively related to liquidity.

Specifically, the ratio of market capitalization to GDP measures the amount of resources attracted for investment and economic growth. Trading volume to GDP proxies the amount of total resources the market attracts and keeps liquid, while trading volume to market capitalization proxies the portion of market capitalization that is liquid and easy to transfer among growth investments. The number of listed companies on stock markets is used to proxy for the financial market's role in attracting growth companies. In essence, bank credit and financial market ratios are proxies for financial development, while GDP growth proxies economic growth.

The institutional and cultural infrastructure of these countries may enhance or mitigate the causality between financial development and economic growth. The economies in most Gulf States are mostly dependent on oil, and on the use of oil money to import products. Thus, the need for financial systems services in these countries may not be as persistent as in those economies that use manufacturing to export goods for national income. A dummy variable (DGULF) is added where the value of one is given to each of the Gulf States and a value of zero otherwise. Another dummy variable (DNOGULF) takes the value of zero for a Gulf State and the value of one otherwise. The interactions between these dummies and financial development variables are used to capture the marginal effects of financial growth variables on economic growth.

We use linear multivariate regressions to assess the effect of financial development on economic growth. The data was tested for heteroscedasticity by using the Pagan-Godfrey test where the error term (the difference between the estimated percentage change in GDP and the actual one) was regressed against the independent variables. The Durban - Watson test was used to assess autocorrelation. We also examined pair wise correlation between the variables and found no significant correlations between variables. Missing observations where estimated by using an autoregressive model for each variable. Observations were discarded when more than two observations were missing. The data was winsorized by setting all data above and below the $99^{\text {th }}$ percentile to the 
$99^{\text {th }}$ percentile. The general regression model is represented by equation 1 :

GGDP = f(M2, CPI, NEXP, DEF, POP, CO, TVCAP, TVGDP, CAPGDP, GGDPL $)$

GGDP is the growth in GDP. M2 is the money aggregate measure and is used to control for monetary policy effects on economic growth while DEF, the budget deficit, controls for fiscal policy. CPI is the consumer price index and controls for the effects of inflation. NEXP, net exports, controls for the effects of international trade. POP is population and is used to control for the effect of population on economic growth. CO is the number of listed companies and proxies the financial market's role in attracting growth companies. TVCAP is the ratio of trading volume to market capitalization and proxies the portion of market capitalization that is liquid and relatively easy to transfer among growth investments. Similarly, TVGDP is the ratio of trading volume to GDP. CAPGDP is the ratio of market capitalization to GDP and measures the amount of resources that the market was able to attract for investment and economic growth. GGDPL is lagged GDP growth. The control variables were dropped from model specifications one at a time to test estimation sensitivity. The pattern of results is not significantly different from the results presented in Table 1 and are not reported in this paper.

Interactions between the dummy variables and the financial development proxies are specified to capture the effects of the distinctive characteristics of two major categories of Middle Eastern economies: oil rich Gulf States and remaining countries. These characteristics are represented in equation 2:

GGDP $=\mathrm{f}(\mathrm{M} 2, \mathrm{CPI}, \mathrm{NEXP}$, DEF, GGDPL, DGUL*CO, DGULF*TVCAP, DGULF*TVGDP, DGULF*CAPGDP, DGULF*CRDTGDP, DNOGULF*CO, DNOGULF*TVCAP, DNOGULF*TVGDP, DNOGULF*CAPGDP, DNOGULF*CRDTGDP)

\section{RESULTS}

The results in Table 1 suggest that the number of listed companies exhibits no significant marginal effect on economic growth. Moreover, the results suggest growth is not significantly related to trading volume, turnover ratios, and market capitalization at the usual levels of statistical significance. A large number of listed companies is a sign of market breadth, an indicator of the market's ability to provide benefits from diversification. The relatively limited number of companies in Middle Eastern markets may make them unattractive to investors because markets may be unable to provide benefits from diversification. Markets in these countries suffer two additional problems. First, a disproportionate number of firms are listed in only one market. Second, many of these firms are not actively traded. The implication is that the number of listed firms may be too small to offer diversification benefits or to attract capital. Both factors may adversely affect market ability to finance growth.

Moreover, the results suggest that economic growth is not significantly related to market capitalization at usual levels of statistical significance. This result is not consistent with the view that market development facilitates growth. However, bank credit is positive and statistically significant at the $1 \%$ level. This result may be a reflection of institutional factors that are unique to Middle Eastern markets. Middle Eastern banks offer informed and more secured credit (Rajan 1992) to finance projects than Middle Eastern bond markets and equity markets [Rajan, (1992); Barakat (2003)]. In addition, Barakat (2003) notes that banks are often shareholders in growth companies and that these shareholdings mitigate the debt holder-equity holder agency conflict. Barakat (2003) also suggests that a high concentration of family ownership and management in these countries mitigates the managementshareholder conflict and encourages banks to extend more credit to growing companies. These views suggest that the institutional factors may favor banks over capital markets as the predominant growth financing mechanism.

The financial development - economic growth relationship may be weaker in Gulf States because of differences in institutional settings between Gulf States and other Middle Eastern countries. If so, interactions between Gulf and Non-Gulf dummy variables and financial development variables may capture these differences. For example, DGULF*CRDTGDP captures the effect of bank credit on economic growth in Gulf States while DNOGULF*CRDTGDP captures the effect of bank credit on economic growth in the other Middle Eastern countries. Table 2 shows the regression results for these two sets of countries. 
The difference in the magnitude and significance of the financial development indicators in Tables 1 and 2 suggests that country specific factors may affect the impact of financial development variables on economic growth. Specifically, the differences between the Gulf and non-Gulf States are captured in bank credit. Table 2 shows that the bank credit coefficient is larger in Gulf States. The marginal effect of bank credit to investment projects is $20.2 \%$ in Gulf States compared with $13.3 \%$ in non Gulf States. This result is consistent with Shoult's (1999) suggestion that intermediation is more advanced in Gulf States.

We also use conventional control variables to isolate their effects from the marginal effects of financial development indicators. Table 2 shows that the growth in GDP is positively correlated with the first lag of growth. M2 is used as a measure of money supply to capture the marginal effect of monetary policy on economic growth. M2 exhibits a significant positive marginal effect of monetary policy on economic growth. CPI controls for inflation and shows that inflation is not significantly related to growth. Some countries in the Middle East have positive net exports due to oil exports and close coordination with the International Monetary Fund (IMF) and World Bank (WB) in the non-oil exporting countries (Barakat, 2003). In turn, export income finances higher levels than would otherwise occur. The results suggest growth is positively related to net exports at the usual levels of statistical significance. Although the budget deficit coefficient is positive, the coefficient is not significant at the usual levels of statistical significance. Interestingly, the difference between the monetary policy coefficient and the budget deficit coefficient is positive and statistically significant. The results also suggest that the population coefficient is positive and significant.

Table 1: Impact of the Level of Financial Development on Economic Growth

\begin{tabular}{cc}
\hline Model & GGDP \\
\hline Intercept & -0.0422 \\
& $(-1.01)$ \\
TVCAP & 0.0006 \\
& $(0.73)$ \\
TVGDP & -0.1696 \\
& $(-1.08)$ \\
CAPGDP & 0.1274 \\
& $(0.68)$ \\
CRDTGDP & 0.0416 \\
& $(0.79)$ \\
GGDPL & $0.1147 * *$ \\
& $(3.18)$ \\
M2 & $0.0001 * *$ \\
& $(2.14)$ \\
CPI & $0.0314 * *$ \\
& $(2.04)$ \\
NEXP & 0.9055 \\
& $(0.27)$ \\
DEF & $0.0083^{* * *}$ \\
& $(3.02)$ \\
POP & 0.0004 \\
& $(1.57)$ \\
Adj. R & 0.0023 \\
F test & $(1.54)$ \\
& 0.51 \\
& $<.0001 * * *$ \\
\end{tabular}


Table 2: Impact of the Level of Financial Development on Economic Growth by Controlling for the Country specific Factors

\begin{tabular}{|c|c|}
\hline Model & GGDP \\
\hline Intercept & $\begin{array}{c}-0.0639 \\
(-1.24)\end{array}$ \\
\hline DCO & $\begin{array}{c}-0.0014 \\
(-0.25)\end{array}$ \\
\hline DTVCAP & $\begin{array}{l}-0.2057 \\
((-1.29)\end{array}$ \\
\hline DTVGDP & $\begin{array}{c}0.1177 \\
(0.72)\end{array}$ \\
\hline DCAPGDP & $\begin{array}{c}0.0740 \\
(1.33)\end{array}$ \\
\hline DCRDTGDP & $\begin{array}{c}0.2019 * * * \\
(4.44)\end{array}$ \\
\hline NDCO & $\begin{array}{c}0.0005 \\
(0.53)\end{array}$ \\
\hline NDTVCAP & $\begin{array}{c}0.3010 \\
(0.85)\end{array}$ \\
\hline NDTVGDP & $\begin{array}{c}-0.3112 \\
(-0.72)\end{array}$ \\
\hline NDCAPGDP & $\begin{array}{l}0.0250 \\
(0.26)\end{array}$ \\
\hline NDCRDTGD & $\begin{array}{c}0.1328 * * * \\
(3.22)\end{array}$ \\
\hline GGDPL & $\begin{array}{c}0.0001 * * \\
(2.27)\end{array}$ \\
\hline M2 & $\begin{array}{c}0.0499 * * * \\
(3.17)\end{array}$ \\
\hline CPI & $\begin{array}{c}0.6987 \\
(0.17)\end{array}$ \\
\hline NEXP & $\begin{array}{c}0.0117 * * * \\
(4.09)\end{array}$ \\
\hline DEF & $\begin{array}{c}0.0005 \\
(1.45)\end{array}$ \\
\hline POP & $\begin{array}{c}0.0041 * * \\
(2.64)\end{array}$ \\
\hline Adj. $\mathrm{R}^{2}$ & 0.65 \\
\hline $\mathrm{F}$ test & $<.0001 * * *$ \\
\hline
\end{tabular}

GGDP: Growth in GDP (\%), M2: A measure of money supply (Millions of USD), CPI: Inflation (\%), NEXP: Net export (Millions of USD), DEF: Government budget deficit (Millions of USD), POP: population, TVCAP: Trading volume to market capitalization (\%), TVGDP: Trading volume to GDP (\%), CAPGDP: Market capitalization to GDP (\%), CRDTGDP: Bank credit to GDP (\%); GGDPL is lagged GDP growth; interaction variables denoted by D represent values where the value of one is given to each of the Gulf States and a value of zero otherwise; interaction variables denoted by $\mathrm{N}$ represent values where the value of one is given to each of the Non-Gulf States and a value of zero otherwise; t-statistics are in parentheses $* * *$ denotes significance at the $1 \%$ level, $* *$ denotes significance at the $5 \%$ level, and * denotes significance at the $10 \%$ level

We estimated regressions using variations of basic model specifications to test the sensitivity of results. For example, regressions were run without lags, without control variables, and without various combinations of control variables. Our results are invariant with respect to model specification. Specifically, financial market variables are not significant while bank variables are.

\section{SUMMARY AND CONCLUSTIONS}

Current theory and practice suggests the development of financial markets and institutions may enhance economic growth by raising the marginal productivity of capital. Financial intermediation affects economic growth by facilitating the trading, hedging, diversifying and pooling of risk, allocating resources, monitoring managers affecting corporate control, and mobilizing savings. We contribute to this literature by assessing results about the 
empirical relationship between various measures of banking and stock market development and long run economic growth in Middle Eastern countries. Generally, financial development has a positive effect on growth, but there are exceptions. The implication is that distinctive market-specific factors may mitigate or enhance these effects. Moreover, the development of stock markets does not appear to facilitate growth, while the development of banking markets does appear to facilitate growth.

An implication of these results for future work is that studies should control for market-specific factors. Specifically, factors that may affect the relationship between financial market and institution development and economic growth are informational inefficiencies, weak law enforcement, government corruption, political instability, reliance on natural resource exports, and reliance on consumer product imports. Moreover, structural factors such as continued development of Islamic banking may affect the relationship between financial institution development and economic growth.

Pagano (1993) suggested that "it is still unclear how and why specific financial markets arise and develop, and whether their development follows some sort of standard sequence. The same applies to the existing body of empirical work. Tests of the models have shown that some of the predicted correlations are indeed present in crosscountry data, but little is known about how the development of different markets affects economic growth". The current paradigm needs to be expanded to include cases where the country's GDP is overwhelmingly dominated by the production of one or very few products, as is the case for the Gulf States with oil. In addition, more research in the area of Islamic banking is needed to further scrutinize the effect of the various Islamic capital gain instruments on economic growth and to test its feasibility as an alternative to interest based instruments. Finally, further research is needed to control for the various aspects of financial markets development to determine the characteristics that enable financial markets to play their hypothesized role in enhancing and promoting financial development.

\section{AUTHOR INFORMATION}

Mounther Barakat serves at the Securities and Commodities Authority in Abu Dahbi, United Arab Emirates. He has also served on the faculty at the University of Houston-Clear Lake and at Fort Hays State University.

Edward Waller is Faculty Chair and Professor of Finance in the Department of Economics, Finance, Marketing and Decision Sciences at the University of Houston-Clear Lake.

\section{REFERENCES}

1. Arrow, K.J. (1964) "The role of securities in the optimal allocation of risk-bearing", Review of Economic Studies Vol 31 No 2, pp. 91-96.

2. $\quad$ Atje R., Jovanovic, B. (1992) 'Stock markets development', European Economic Review Vol 37, pp. 632640.

3. Barakat, M. (2003), The Determinants of Borrowing in the Arab World, Oklahoma State University, US.

4. Bencivenga, V., Smith, B. (1991) "Financial Intermediation and Endogenous Growth", The Review of Economic Studies Vol 58 No 2, pp. 95-209.

5. Booth, L., Aivazian, V., Demirguc-Kunt, A., Maksimovic, V. (2001) "Capital Structures in Developing Countries", Journal of Finance Vol 54, pp.87-130.

6. $\quad$ Debreu, G. (1959), Theory of Value, Wiley, New York.

7. Demeriguc-Kunt, A., Maksimovic, V. (1996) "Funding Growth in Bank-Based and Market-Based Financial Systems: Evidence from Firm Level Data", Journal of Financial Economics Vol 65, pp. 337-363.

8. Devereux, M.B., Smith, G.W. (1991), "International risk sharing and economic growth", Discussion paper no. 829, Department of Economics, Queen's University, Kingston, Ont.

9. Diamond D.W. Dybvig, P.H., (1983) "Bank runs, deposit insurance, and liquidity”, Journal of Political Economy Vol 91, pp. 401-419.

10. Edwards, W., (2000), Key Financial Instruments, Prentice Hall, England.

11. Albayan Publications, (2002), Statistics and Database, Albayan, UAE.

12. Filer, Randall, K., Hanousek, J., Nauro, C. (1999) “Do stock markets promote economic growth?”, William Davidson Institute Working Paper no. 267, University of Michigan. 
13. Garretsen, H., Lensink, R., Sterken, E. (2004) “Development of Stock Markets, Societal Norms and Legal Institutions”, Journal of International Financial Markets, Institutions and Money Vol 14, pp. 165-183.

14. Goldsmith, R.W. (1969), Financial Structure and Development. Yale University Press, New Haven, CT.

15. Greenwood, J., Jovanovic, B. (1990) "Financial Development, Growth, and the Distribution of Income", Journal of Political Economy Vol 98 No 5, pp. 1076-1107.

16. Harris, R.D.F. (1997) "Stock Markets and Development: A Re-Assessment", European Economic Review Vol 41, pp. 139-146.

17. Information Guide, (1990), Doing Business in Bahrain, Price Waterhouse, NY.

18. Jappelli, T., Pagano, M., (1992) "Saving, Growth and Liquidity Constraints", Discussion Paper CEPR, n.662. London.

19. King, R., Levine, R. (1992) "Financial Indicators and growth in a cross section of countries", Working paper no. 819, The World Bank, Washington. DC.

20. King, R. Levine, R. (1993) "Financial Intermediation and Economic Development. Financial intermediation in the construction of Europe", Eds: COLIN

21. King, R. Levine, R. (1993) "Finance and Growth: Schumpeter Might Be Right", Quarterly Journal Economic Vol 108 No 3, pp. 717-37.

22. LaPorta, R. Lopez-de-Silanes, F., Shleifer, A., Vishny, R., (1997) "Legal Determinants of External Finance", Journal of Finance Vol 52, pp. 1131-1150.

23. LaPorta, R. Lopez-de-Silanes, F., Shleifer, A., Vishny, R. (1998) "Corporate Ownership Around the World", Journal of Finance Vol 54, pp. 471-517.

24. Levine, R. (1991) "Stock Markets, Growth, and Tax Policy”, The Journal of Finance Vol 46, pp. 14451465.

25. Levine, R. (1997) "Financial Development and Economic Growth: Views and Agenda", Journal of Economic Literature Vol 35 No 2, pp. 688-726.

26. Levine, R., Zervos, S. (1998) "Stock Markets, Banks, and Economic Growth", American Economic Review Vol 88 No 3, pp. 537-58.

27. McKinnon, R. (1973), Money and capital in economic development. Brookings Institution, Washington, D.C.

28. MEDEA, (2000), Islamic Banks, European Institute for Research on Mediterranean and Euro Arab Cooperation, EEC.

29. Merton, R. C, Bodie, Z. (1995), A conceptual framework for analyzing the financial environment. Harvard Business School Press.

30. Pagano, M. (1993) "Financial Markets and Growth: An Overview”, European Economic Review Vol 37 No 2, pp. 613-22.

31. Rajan, R.G. (1992) “Insiders and Outsiders: The Choice between Informed and Arm's-Length Debt", Journal of Finance Vol 47, pp. 1367-1400.

32. Rajan, R. G., Zingales, L. (1998) "Financial Dependence and Growth", American Economic Review Vol 88, pp. 559-586.

33. Roubini, N., Sala-y-Martin, X. (1991) "Financial Development, the Trade Regime, and Economic Growth”, Working paper no. 3876, NBER, Cambridge, MA.

34. Roubini, N., Sala-y-Martm, X. (1992) “A growth Model of Inflation, Tax Evasion and Financial Repression”, Working paper no. 4062, NBER, Cambridge. MA.

35. Saint-Paul, G. (1992) “Technological Choice, Financial Markets, and Economic Development”, European Economic Review Vol 36 No 4, pp. 763-781.

36. Shaw, E. S. (1973), Financial deepening m economic development. Oxford University Press, New York.

37. Shoult, A., (1999), Doing Business with Saudi Arabia. Kogan Page, London.

38. Sussman, 0. (1991) "A theory of financial development", Working paper no. 233. The Hebrew University of Jerusalem, Jerusalem.

39. Tsiddon, D. (1992) “A Moral Hazard Trap to Growth”, International Economic Review Vol 33, pp. 299321 . 
NOTES 